\title{
Anatomical features of three perennial swampy plants of Poaceae, grown on the water stream banks in Nile Delta, Egypt
}

\author{
Ahmed M. Abd El-Gawad*, Yasser A. El-Amier \\ Botany Department, Faculty of Science, Mansoura University, Mansoura 35516, Egypt
}

\begin{abstract}
The anatomical structure of plants is largely varied according to genetics as well as the environmental conditions. The present study aims to describe the anatomical features of three species of family Poaceae growing naturally in canal bank habitat namely: Arundo donax, Pennisetum setaceum and Saccharum spontaneum. These plants are referred as medicinal, grazing or fiber producing plants. Samples were obtained from the canal banks in Nile delta of Egypt. The samples were fixed in formalin-acetoalcohol and cross sections were prepared, examined using full automatic Olympus microscope and photographed at different power. In the present study, regarding leaves, the general appearance of the leaves sections showed either flat or V-shaped blade. The leaf blades of the three plants show a typical monocot organization. The mesophyll cells showed no distinct differentiation into palisade or spongy tissue. In $P$. setaceum and $S$. spontaneum, the leaves have distinct bulliform cells which enable the leaf to fold or roll. The vascular bundles of leaves are collateral, closed, numerous and diffuse in distribution. The vascular bundles are larger in size and surrounded by a sheath of fibers. However, the cross-section of the stem is more or less circular. Ground tissue is parenchymatous and not differentiated into cortex and pith in $P$. setaceum and $S$. spontaneum, while $A$. donax has large hollow pith. The bundles are collateral and are usually surrounded by a sclerenchymatous sheath.
\end{abstract}

Key words:

Grasses, anatomy, swampy habitat, water streams

Received:

18 September 2017

Accepted:

25 December 2017

Published:

31 December 2017

*Corresponding Author: Ahmed M. Abd El-Gawad Botany Department, Faculty of Science, Mansoura University, Mansoura 35516, Egypt

Email:

dgawad84@

mans.edu.eg /

dgawad84@

yahoo.com

Citation:

Abd El-Gawad, A. M., Y. A. El-Amier. (2017). Anatomical features of three perennial swampy plants of Poaceae, grown on the water stream banks in Nile Delta, Egypt. Journal of Medicinal Botany, 1, 58-64. doi: 10.25081/jmb.2017.v1.863

\section{Introduction}

Plant anatomical structure of the plants is mainly influenced by the genetics or the environmental factors (Sattler and Rutishauser, 1997; Meng and Mao, 2013). Therefore, the anatomical feature gives an indication of the phylogeny as well as the habitat features and/or structure (Cai and Guo, 1995; Liu, 2006). Poaceae (Gramineae family) is monocotyledonous flowering plants with around 780 genera and around 12,000 species. Grasses have usually hollow stems and leaf is the blade. Grass leaves are narrow alternate leaves borne singly at the nodes and the lower part of each leaf encloses the stem, forming a leaf-sheath (Christenhusz \& Byng, 2016). After the other big families, Poaceae are the fifth-largest plant family (Byng, 2014).

The grass family is of particular interest to humans. Many species of grasses are most economically important plant family in human life (Cope and Gray, 2009; Kellogg, 2001). The grass family is highly economically exploited (Christenhusz \& Byng, 2016). In addition, grasses family is ecological dominants, which currently comprise approximately $15 \%$ of

CThis article is open access and licensed under the terms of the Creative Commons Attribution License (http://creativecommons.org/licenses/by/4.0/) which permits unrestricted, use, distribution and reproduction in any medium, or format for any purpose, even commercially provided the work is properly cited. Attribution - You must give appropriate credit, provide a link to the license, and indicate if changes were made. 
monocots species diversity of the earth's land surface (Clark, 2004).

Structurally, in grasses some of the species, there are formation of tube like structures by the leaves during water stress. Several terrestrial plant species of family Poaceae were studied from the anatomical point of view (Kellogg, 2015; Dogan, 1985, 1997; Dogan and Tosunoglu, 1992; Panizzo et al., 2017). However, little studies dealt with the anatomy of swampy grasses. Therefore, the present investigation contributes to the anatomical features of three species of family Poaceae growing naturally in canal bank habitat namely: Arundo donax, Pennisetum setaceum and Saccharum spontaneum.

\section{Materials and methods}

\section{Plant specimen's collection and preparation}

Arundo donax Pennisetum setaceum and Saccharum spontaneum samples were collected from its habitat on the border of water streams within the Nile delta (see the location data Table 1). The samples were identified following Boulos (2005). About $50 \mathrm{~mm}$ specimen of fresh leaves and stems were taken from the healthy plants and directly placed in vials containing a fixative (Formalin-Aceto-Alcohol, 10:5:85, v \v).

\section{Anatomical study}

We followed the methods designed by Jensen (1962) and Peacock and Bradbury (1973) to investigate the anatomical characters of the plant samples.
Dehydration and infiltration of plant samples

The collected specimens were dehydrated using various concentrations (50, 70, 85 and $95 \%$ ) of tertiary butyl alcohol (TBA) and the tissues were allowed to remain in each change for $3 \mathrm{~h}$. and finally kept overnight in absolute TBA to be completely dehydration.

The dehydrated samples were carefully infiltrated with paraffin wax, where soft paraffin wax was infiltrated into the samples, followed by melted hard paraffin wax and heated in an oven at $60^{\circ} \mathrm{C}$ for $48 \mathrm{hrs}$. and let to complete solidification. The specimens were mounted into the middle of a block of melted paraplast wax, let to cool in order for complete solidification, and stored in a refrigerator.

\section{Sectioning and photographing of plant samples}

The Sectioning and photographing of plant samples were done by following Esau (1977) and Fahn (1982) standard methods and as described previously (El-Amier and El-Gawad, 2017). Ideal sections were examined using Olympus microscope and different pictures of various plant organs were taken and described.

\section{Results and discussion}

Salient ecological features of studied grasses (A. donax, P. setaceum and S. spontaneum) in the present study are shown in (Table 1). These species are naturally growing in different habitats of the Nile Delta including high ways, fields of orchards, canals, drains, abandoned fields and lakes. Moreover, the anatomical investigation of these species has been described in the present study as following:

Table 1. Salient ecological features of studied grasses.

\begin{tabular}{lllllc}
\hline Scientific name & Vernacular name & Life form & Chorotype & Habitat & Location data \\
\hline Arundo donax L. & Ghaab & G, He & Cult.\& Nat. & Rw, Hw, Or, Ca & $30^{\circ} 47^{\prime} 25.6^{\prime \prime N}$ \\
$31^{\circ} 15^{\prime} 36^{\prime \prime} \mathrm{E}$ & $31^{\circ} 07^{\prime} 05.2^{\prime \prime N}$ \\
Pennisetum setaceum (Forssk.) Chiov. & Sabat, Hadaa & H & ME+PAL & Ca, Or & $31^{\circ} 51^{\prime} 56.5^{\prime \prime} \mathrm{E}$ \\
Saccharum spontaneum L. & Heesh & G, He & ME+PAL & Rw, Hw, Af, Ca, & $31^{\circ} 06^{\prime} 41.7^{\prime \prime N}$ \\
& & & Dr, La & $31^{\circ} 39^{\prime} 16.9^{\prime \prime} \mathrm{E}$ \\
\hline
\end{tabular}

G: Geophytes, He: Helophytes, H: Hemicryptophytes, ME: Mediterranean, PAL: Palaeotropical, Rw: Railways, Hw: High ways, Or: Fields of orchards, Ca: Canals, Dr: Drains, Af: Abandoned fields, La: Lake. 


\section{Arundo donax}

The outline of the stem is more or less circular as well as has wide hollow pith (Fig. 1). There are continuous cylinders of sclerenchyma cells close to the periphery. The outer smaller vascular bundles are embedded in this sclerenchyma. Widely spaced vascular bundles of closed type are scattered throughout the crosssection of the stem and surrounded by a sclerenchymatous sheath. In this context, the good reeds have a smaller size of parenchyma cells in the cortex (Veselack, 1979), however, this has not been confirmed in the present investigation. The stiffness of the $A$. donax wood was referred to the high amount of fiber in the inner cortex (Spatz et al., 1997). This result is in harmony with other related studies (Giełwanowska et al., 2005; Guo and Miao, 2010; Kolesik et al., 1998). Moreover, the anatomical characteristics of $A$. donax showed a high content of fibers and give a prediction of the potential use of this crop for fiber production (Shatalov and Pereira, 2005).
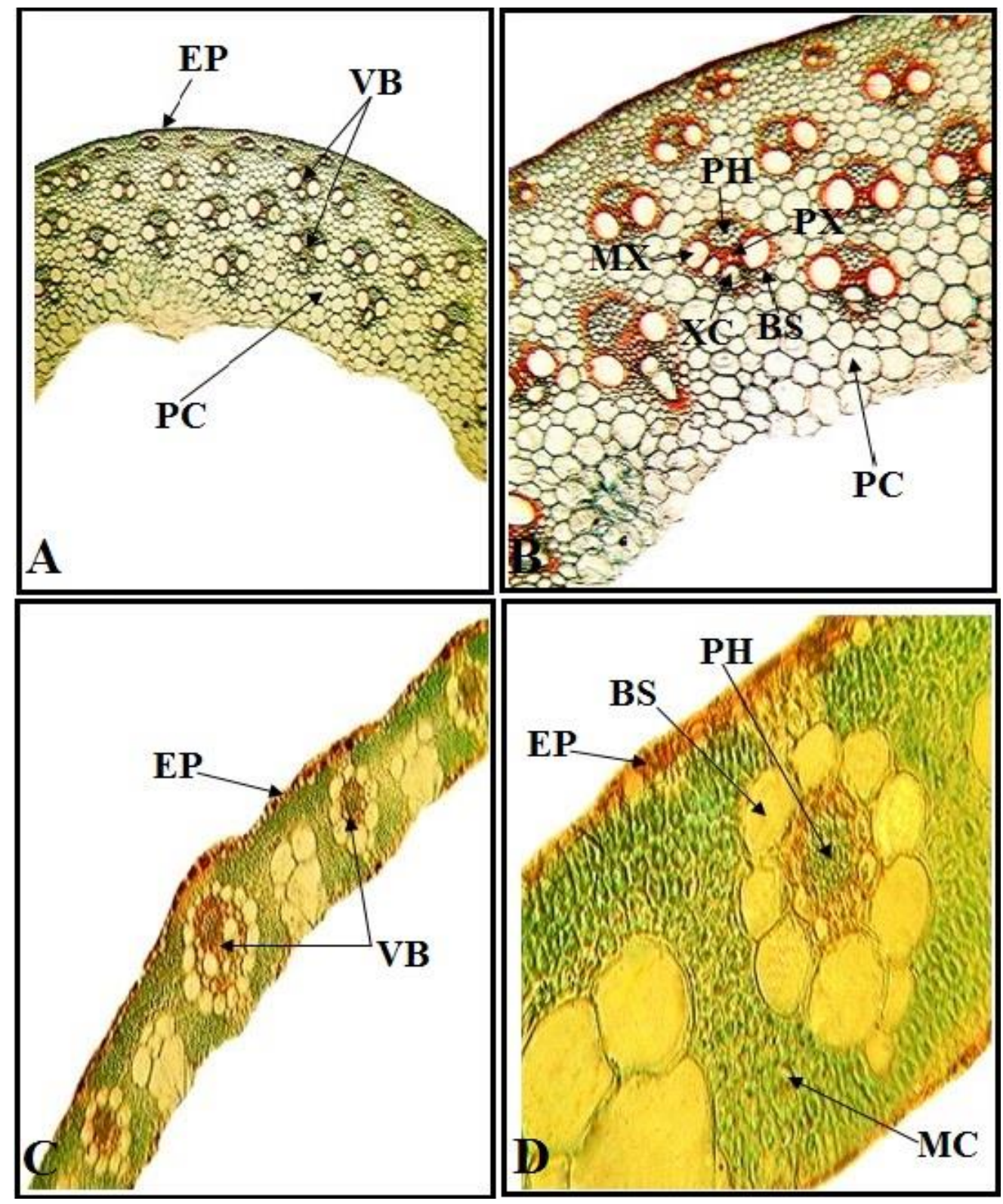

Fig 1. Cross sections of Arundo donax L. stem and leaf. A: stem, B: magnified part of stem, C: whole leaf, D: magnified part of leaf, BS: bundle sheath, EP: epidermis, MC: mesophyll cell, MX: metaxylem, PC: parenchyma cells, PH: phloem, PX: protoxylem, VB: vascular bundle and XC: xylem cavity. 
Arundo donax leaf blades cross sections show a typical monocot organization. The leaf is an example of the isobilateral mesophyll with palisade parenchyma on both sides of the adaxial and abaxile side (Fig. 1). The isobilateral leaf of A. donax is thick and has palisade cells with large lacunae and alternate with a region of spongy parenchyma (Fig. 1). In the middle portion, there is a large vascular bundle covered by two bundles sheaths, an inner one called the mestome sheath which have thick-walled cells. In mestome sheath there is an outer sheath larger thin-walled cells which are surrounded by mesophyll cells, which is typical Kranz anatomy structure (Esau, 1997).

\section{Pennisetum setaceum}

The stem of $P$. setaceum is more or less circular (Fig. 2). The epidermal patterns attained a high degree of specialization and differentiation in the family Poaceae (Raju et al., 1986). There are continuous cylinders of sclerenchyma below the epidermis. The outer smaller vascular bundles are embedded in this sclerenchyma. Fiber strands occur between the small bundles and the epidermis and strands of chlorenchyma alternate with the fiber strands (Fig. 2). Widely spaced vascular bundles of closed type are scattered throughout the cross-section of the stem. The bundles are collateral and are usually surrounded by a sclerenchymatous sheath.

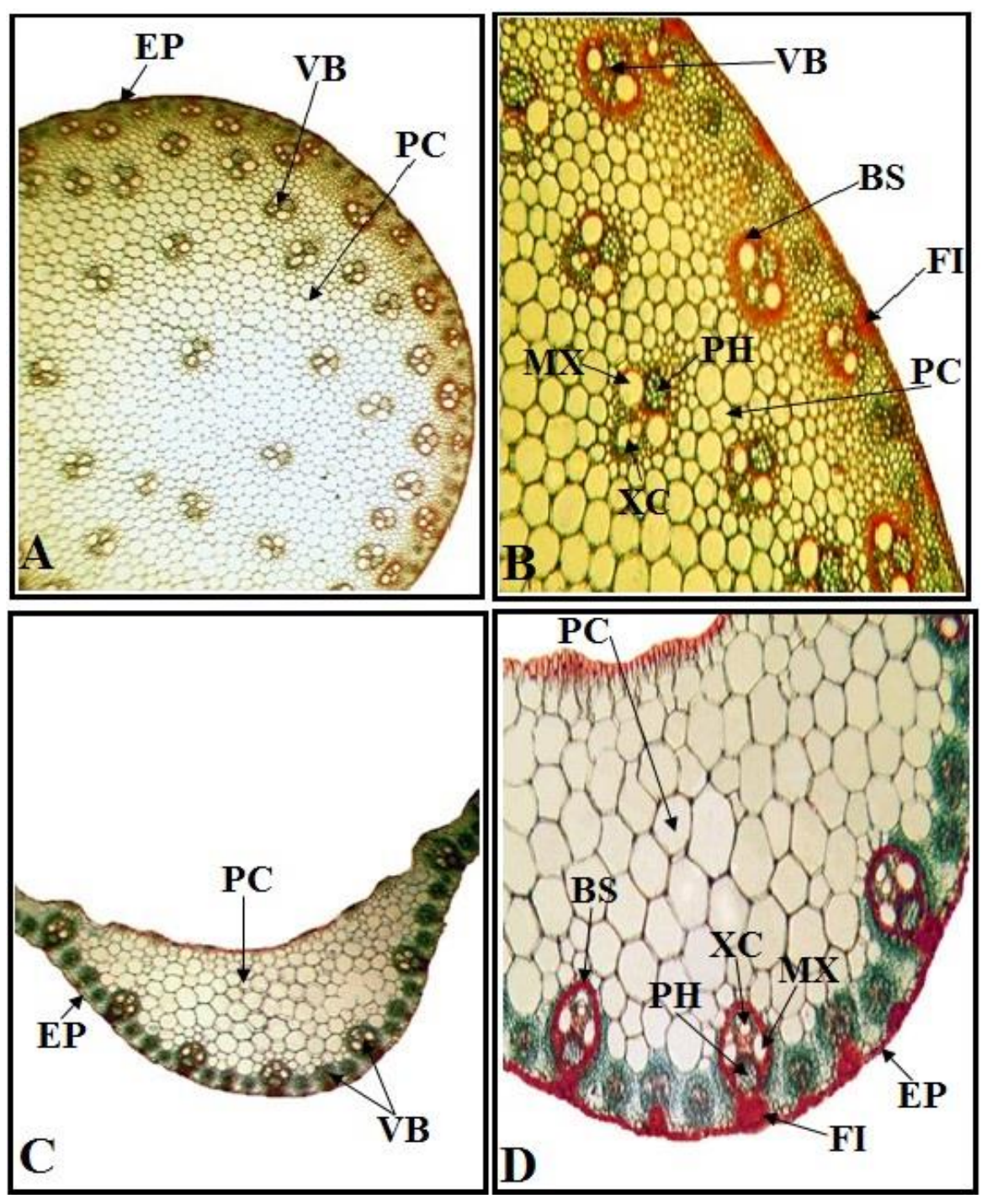

Fig. 2. Cross sections of Pennisetum setaceum (Forssk.) Chiov. stem and leaf. A: stem, B: magnified part of stem, C: whole leaf, D: magnified part of leaf, BS: bundle sheath, EP: epidermis, FI: fibres, MX: metaxylem, PC: parenchyma cells, PH: phloem, VB: vascular bundle and XC: xylem cavity. 
Lamina of $P$. setaceum is wide as well as thick. The adaxial surface is supported by a wide and thin plate of hypodermal sclerenchyma (Fig. 2). $P$. setaceum leaves have developed sclerenchyma commonly fibers appear in longitudinal plates extending from the large vascular bundle to the epidermis (Fig. 2). The mesophyll of P. setaceum showed no distinct differentiation into palisade and spongy parenchyma. Vascular bundles are of different sizes alternate with one another and surrounded by bundle sheath. The middle bundles along the lower epidermis may be the largest or the median part of the blade is thickened on the adaxial side represent the typical monocot type. However, most vascular bundles are small, crowded and angular. Metcalfe (1960) observed that the leaf anatomical characters showed considerable variation in the family Poaceae.
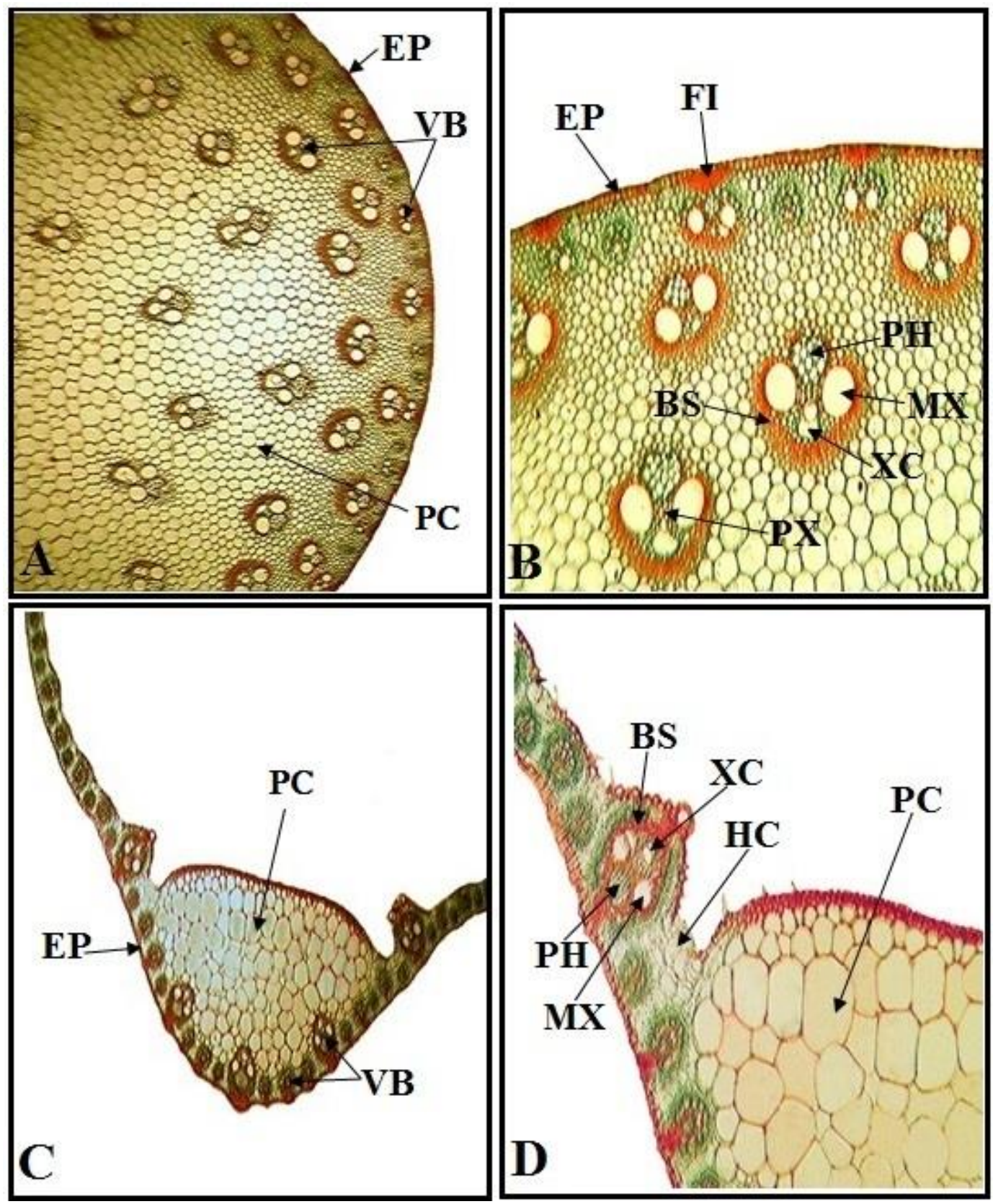

Fig. 3. Cross sections of Saccharum spontaneum L. stem and leaf. A: stem, B: magnified part of stem, C: whole leaf, D: enlarged part of leaf, BS: bundle sheath, EP: epidermis, FI: fibres, HC: hing cells, MX: metaxylem, PC: parenchyma cells, PH: phloem, PX: protoxylem, VB: vascular bundle and XC: xylem cavity. 


\section{Saccharum spontaneum}

The cross-section of the $S$. spontaneum stem is more or less circular (Fig. 3). There are continuous cylinders of sclerenchyma close to the periphery. $S$. spontaneum contained high fiber content, where this is in harmony with other species (Silveira et al., 2016). Ground Tissue is parenchymatous without the demarcation cortex and pith. The outer cells are smaller and angular with thick walls (figure 3 ).

In middle portion, the cells are larger with wavy structure. Moreover, the epidermis is uniseriate and continuous. The epidermal cells of the leaf show cell contents. The cells in the region of hypodermal are uniform with thin walls. Enlarged epidermal cells with thin anticlinal walls, referred to as bulliform cells, and are often described as cells participating in leaves. The bulliform cells become flaccid enabling the leaf to fold or to roll (Wang, 2005). In this context, bulliform cells are commonly found in various plant families included in Poaceae, Cyperaceae, and Juncaceae (Grigore and Toma, 2017).

There are many un evenly arranged vascular bundles with varying size and shape. In outer portion they are more or less circular in shape, where they are collateral and closed. They have two narrow metaxylem elements and small protoxylem elements. The vascular bundle is surrounded by a sheath of fibers. However, central vascular bundles are larger in size, have two metaxylem elements, one or two intact protoxylem elements and generally a protoxylem lacuna.

In conclusion, the anatomical feature of the studied swamp plant species reflects the adaptation of plants to different environmental variables paralleled with morphological, ecophysiological and growth responses (Peng et al., 2017). Moreover, $A$. donax and P. setaceum could be good candidates for fiber production industry due to high content of fibers.

\section{Author contributions}

Both authors collected plant samples, conceived the laboratory work and wrote the manuscript.

\section{References}

Boulos, L. (2005). Flora of Egypt (Vol. 4) Monocotyledons (Alismataceae-Orchidaceae). Cairo, Egypt: Al-Hadara Publishing.

Byng, J.W. (2014). The Flowering Plants Handbook. Plant Gateway, Hertford.

Cai, L.B. \& Guo, Y.K. (1995). Studies on constituent cells of leaf epidermis, systematics and phylogenetic path of the family Poaceae. Acta Botanica BorealiOccidentalia Sinica, 15(4): 323-335.

Christenhusz, M.J.M. \& Byng, J.W. (2016). The number of known plants species in the world and its annual increase. Phytotaxa-Magnolia Press, 261(3), 201-217.

Clark L. (2004). The grasses (Poaceae): Robert Brown and now. Telopea, 10: 505-514.

Cope, T. \& Gray, A. (2009). Grasses of the British Isles. Botanical Society of Britain and Ireland, London, U.K.

Dogan M. \& Tosunoglu, C. (1992). A numerical analysis of leaf blade morphology and its possible implication over the infrageneric delimitation in the genus Helictotrichon s.l (Gramineae). Turkish Journal of Botany, 16: 365-372.

Dogan M. (1985). Comparative reproductive morphology of Turkish grasses. Doga Bilim Dergisi A2: 196-213.

Dogan M. (1997). Numerical taxonomic study on the genus Alopecurus L. (Gramineae). Ot Sistematik Botanik Dergisi, 4: 71-76.

El-Amier, Y. A., \& El-Gawad, A. M. A. (2017). Anatomical investigation of three emergent Cyperus species growing naturally on the canal banks of the Nile delta, Egypt. Journal of Scientific Agriculture, 1, 294-299.

Esau, K. (1977). Anatomy of Seed Plants, 2 $2^{\text {nd }}$ edition. John Wiley and Sons, New York.

Fahn, A. (1982). Plant Anatomy. $3^{\text {rd }}$ edition. Pergamon Press, Oxford.

Giełwanowska, I., Szczuka, E., Bednara, J., \& Gorecki, R. (2005). Anatomical features and ultrastructure of Deschampsia antarctica (Poaceae) leaves from different growing habitats. Annals of Botany, 96(6): 1109-1119.

Grigore, M. N., \& Toma, C. (2017). Bulliform cells. In: Anatomical Adaptations of Halophytes. Springer, Cham, Switzerland. pp. 325-338. 
Guo, Z. H., \& Miao, X. F. (2010). Growth changes and tissues anatomical characteristics of giant reed (Arundo donax L.) in soil contaminated with arsenic, cadmium and lead. Journal of Central South University of Technology, 17(4): 770-777.

Jensen, W. A. (1962). Botanical Histochemistry. San Francisco: Freeman.

Kellogg E. A. (2015). Description of the Family, Vegetative Morphology and Anatomy. In: Flowering Plants. Monocots. The Families and Genera of Vascular Plants, (Vol. 13). Springer, Cham, Switzerland.

Kellogg, E. A. (2001). Evolutionary history of the grasses. Plant Physiology, 125(3): 11981205.

Kolesik, P., Mills, A., \& Sedgley, M. (1998). Anatomical characteristics affecting the musical performance of clarinet reeds made from Arundo donax L. (Gramineae). Annals of Botany, 81(1): 151-155.

Liu, M. (2006). Morphology and Anatomy of Seed Plant, $3^{\text {rd }}$ edition. Science Press, Beijing, China.

Meng, L., \& Mao, P. (2013). Micromorphological and anatomical features of four species of Elytrigia Desv. (Poaceae). Bangladesh Journal of Plant Taxonomy, 20(2), 135-144.

Metcalfe, C. R. (1960). Anatomy of Monocotyledones. I. Gramineae. Clarendon Press, Oxford.

Panizzo, C. C., Fernández, P. V., Colombatto, D., Ciancia, M., \& Vega, A. S. (2017). Anatomy, nutritional value and cell wall chemical analysis of foliage leaves of Guadua chacoensis (Poaceae, Bambusoideae, Bambuseae), a promising source of forage. Journal of the Science of Food and Agriculture, 97(4): 1349-1358.

Peacock, P. \& Bradbury, S. (1973). Peacock's Elementary Microtechnique, $4^{\text {th }}$ edition. Edward Arnold, London:.

Peng, Y., Zhou, Z., Tong, R., Hu, X., \& Du, K. (2017). Anatomy and ultrastructure adaptations to soil flooding of two full-sib poplar clones differing in floodtolerance. Flora, 233: 90-98.

Raju, M. S., Seshavatharam, V. \& Rao, S. A. (1986). Contribution to the leaf anatomy of the genus Pennisetum Rich. Proceedings of the Indian Academy of Science, 96(2): 113-120.
Sattler, R., \& Rutishauser, R. (1997). The fundamental relevance of morphology and morphogenesis to plant research. Annals of Botany, 80(5): 571-582.

Shatalov, A. A., \& Pereira, H. (2005). Arundo donax L. reed: new perspectives for pulping and bleaching. Part 4. Peroxide bleaching of organosolv pulps. Bioresource technology, 96(8): 865-872.

Silveira, L. C. I. D., Brasileiro, B. P., Kist, V., Weber, H., Daros, E., Peternelli, L. A., \& Barbosa, M. H. P. (2016). Selection in energy cane families. Crop Breeding and Applied Biotechnology, 16(4): 298-306.

Spatz, H. C., Beismann, H., Bruchert, F., Emanns, A. \& Speck, T. (1997). Biomechanics of the giant reed Arundo donax. Philosophical Transactions of the Royal Society of London B, 352: 1-10.

Veselack, M. S. W. (1979). Comparison of cell and tissue differences in good and unusable clarinet reed. $\mathrm{PhD}$ Thesis. Ball State University, Muncie, Indiana, USA.

Wang, Y. J. (2005). Bulliform cell of grass family. Biology Education, 30(11): 7-9. 